\title{
Development and Validation of the Determination of Sorafenib in Human Plasma using Tandem Mass Spectrometry Coupled with Liquid Chromatography
}

\author{
Daejin Park', Sunggon $\mathrm{Lee}^{2}$ and Woomi Kim${ }^{1}$ * \\ ${ }^{1}$ Departments of Pharmacology and ${ }^{2}$ Family Medicine, Kosin University College of Medicine, Busan 602-702, Korea \\ Received October 19, 2012 /Revised November 8, 2012 /Accepted November 8, 2012
}

\begin{abstract}
Sorafenib is a multikinase inhibitor and an oral anticancer drug approved for the treatment of patients with advanced renal cell carcinoma and those with unresectable hepatocellular carcinoma. The purpose of this study was to develop an efficient method of the determination of sorafenib in human plasma using tandem mass spectrometry coupled with liquid chromatography (LC/MS/MS) and validate the method by the guidelines of the Korean Food and Drug Administration (KFDA). Plasma samples $(100 \mu \mathrm{l})$ were added with chlorantraniliprole as an internal standard and then mixed with the $0.1 \%$ formic acid-containing extraction solution composed of isopropyl alcohol and ethyl acetate (1:4, $\mathrm{v} / \mathrm{v}$ ). After centrifugation, the supernatant was concentrated at $45^{\circ} \mathrm{C}$ under negative pressure and centrifugal force. The residue was reconstituted with a mobile phase and injected into the HPLC instrument using a reverse phase Waters XTerra ${ }^{\mathrm{TM}} \mathrm{C} 18$ column (particle size $3.5 \mu \mathrm{m}$ ). Liquid chromatography was carried out within the run time of 5 min using a mobile phase composed of buffer $(0.1 \%$ formic acid and $10 \mathrm{mM}$ ammonium formate), methanol, and acetonitrile (1:6:3, v/v/v). The analytes were monitored by tandem mass spectrometry in the multiple reaction monitoring method programmed to detect sorafenib at ' $\mathrm{m} / \mathrm{z} 465.2 \rightarrow 252.5^{5}$ ' and chlorantraniliprole at ' $\mathrm{m} / \mathrm{z} 484.4 \rightarrow 286.2^{\prime}$ ' with positive electrospray ionization mode $\left(\mathrm{ES}^{+}\right)$. The result showed the proper linearity $\left(r^{2}>0.99\right)$ over the range of 2,000-5,000 ng/ml with good accuracy $(90.7-103.9 \%$ ) and precision (less than $10 \%$ ). The newly developed method using LC/MS/MS was validated by the guideline of KFDA and identified as more sensitive compared to the previous methods.
\end{abstract}

Key words : Anticancer drug, sorafenib, chlorantraniliprole, LC, MS, MS, tandem mass spectrometry coupled with liquid chromatography

\section{Introduction}

Sorafenib is an oral anticancer drug with the structure of diphenylurea derivative (Fig. 1). The anticancer targets inhibited by this drug are several protein kinases that are members of the Raf family of kinases, cell surface tyrosine kinases, vascular endothelial growth factor receptors (VEGFR), and platelet derived growth factor receptors (PDGFR) [8]. These protein kinases are directly related with regulation of multiple aspects of cancer growth like angiogenesis and multiplication. In cancer cell lines studies, sorafenib has shown potent antitumor activity against a variety of human cancer cell lines, including human colon, lung, breast and ovarian [9]. FDA-approved indication of sorafenib was the treatment of patients with advanced renal cell carcinoma (RCC) and those with unresectable hep-

*Corresponding author

Tel : +82-51-990-6437, Fax : +82-51-990-3081

E-mail : kwm@kosinmed.or.kr atocellular carcinoma (HCC) $[2,5]$.

In phase I studies with patients with advanced solid tumors, pharmacokinetic parameters had a considerable interpatient variability but increased $\mathrm{C}_{\max }$ and $\mathrm{AUC}_{0-12}$ in plasma correlate with increased dose frequency and total dose [3]. For example, interpatient coefficient of variation was $70 \%$ in 22 patients in whom $\mathrm{AUC}_{0-24}$ was calculated after a single $100 \mathrm{mg}$ oral dose. However, by increasing oral daily doses to $400 \mathrm{mg}$, the therapeutic range of the most patients could be achievable although the large interpatient variability. Accordingly, it was chosen with the dosage of $400 \mathrm{mg}$ per day for oral administration in phase III studies with patients with RCC and HCC [2,5]. However, in that case, the incidence of toxicity would increase. If the dose is optimized by the pharmacokinetic modulation, it could not be overdosed. The specific and accurate quantification method of sorafenib is essential to explore the pharmacokinetic profile of sorafenib. In the beginning of sorafenib development, analytical methods based on reversed-phase high perform- 
<smiles>CNC(=O)c1cc(Oc2ccc(NC(=O)Nc3ccc(Cl)c(C(F)(F)F)c3)cc2)ccn1</smiles>

Sorafenib

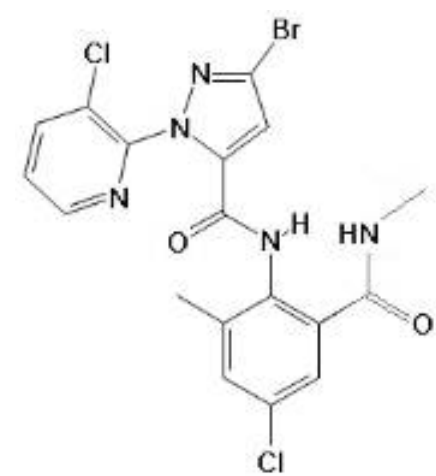

Chlorantraniliprole

Fig. 1. Structures of sorafenib and chlorantraniliprole.

ance liquid chromatography (HPLC) have been reported for the quantitative determination of sorafenib in mouse plasma [1]. The method had the selectivity and the linearity over the concentration range of $80-2,000 \mathrm{ng} / \mathrm{ml}$. Recently, the more precise methods with lower limit of quantification are published using tandem mass spectrometry coupled with HPLC (LC/MS/MS) [10]. That method was 10 times more sensitive than the previous HPLC method of which lower limit of quantification was $80 \mathrm{ng} / \mathrm{ml}$. The chromatographic run time was reduced from 35 to $6 \mathrm{~min}$ so that it could make it faster to analyze a large number of plasma samples. Here, we describe a more rapid and sensitive method for the determination of sorafenib in human plasma based on LC/MS/MS with electrospray positive ionization.

\section{Materials and Methods}

\section{Chemicals and reagents}

Sorafenib was supplied by Bayer HealthCare (Leverkusen, Germany) in the form of film-coated tablets composed of sorafenib tosylate (200 $\mathrm{mg}$ as a sorafenib) and other additives (roscarmellose sodium, microcrystalline cellulose, hypromellose, sodium lauryl sulphate, magnesium stearate, polyethylene glycol, titanium dioxide, ferric oxide red and so on). Chlorantraniliprole (CAS number: 500008-45-7), internal standard, was purchased from Sigma (st. Louis, MO, USA). Acetonitrile, methanol, ethyl acetate, isopropanol, ammonium formate and formic acid were obtained from Merck (KGaA, Darmstadt, Germany). All solvents had high analytical grade for HPLC or mass spectrometry. Human pooled plasma and six individual human plasma were purchased from Biochemed (Winchester, VA, USA) and certificated to be healthy and drug-free volunteers (20-30 ages, both sex).
Water was deionized by a Milli-Q water purification system (Millipore, Bedford, MA, USA).

\section{Sample preparation}

Stock solutions of sorafenib and chlorantraniliprole were prepared with $80 \%$ methanol to the concentration of 1 $\mathrm{mg} / \mathrm{ml}$ and were kept at $-70^{\circ} \mathrm{C}$. Working solutions (10-fold standard solutions) of sorafenib were obtained by serial dilutions of stock solutions at the following concentration: 0.02, $0.05,0.5,1,5,10,50 \mu \mathrm{g} / \mathrm{ml}$ with $80 \%$ methanol. Working solution of chlorantraniliprole was also prepared at the concentration of $10 \mu \mathrm{g} / \mathrm{ml}$. Before extraction, Each $100 \mathrm{ul}$ volume of standard solution was prepared by mixing $90 \mathrm{ul}$ blank plasma with $10 \mathrm{ul}$ working standard solution to achieve final concentrations of 2, 5, 50, 100, 500, 1,000, 5,000 $\mathrm{ng} / \mathrm{ml}$ and all plasma solutions were added with 10 ul working solution of chlorantraniliprole used as internal standard (IS). After mixing with IS, a 900 ul of extraction solution was added to the standard solution in a $2 \mathrm{ml}$ mini-eppendorf tube. The mixture was vortex-mixed for 5 minutes and centrifuged at 13,500 rpm for 10 minutes. Extraction solution consisted of organic solutions mixed with ethyl acetate and isopropanol in ratio of $4: 1(\mathrm{v} / \mathrm{v})$ containing with $0.1 \%$ formic acid. A 800 ul volume of the organic top layer was transferred to another tube and evaporated to dryness in a Centrivap mobile system (Labconco, Kansas, MO, USA) for $60 \mathrm{~min}$ at $45^{\circ} \mathrm{C}$ on centrifugal negative pressure. The residue was reconstituted in 100 ul mobile phase and filtered through a $0.22 \mathrm{um}$ PVDF filter in $1 \mathrm{ml}$ syringe (Norm-ject) with Luer-lock tip. Filtered solution was transferred to 300-ul insert equipped in a 2-ml polypropylene autosampler vial sealed with a Teflon crimp cap. A 5 ul volume of the filtrate was injected to the column part from the autosample 
management system of HPLC system having the temperature of $10^{\circ} \mathrm{C}$. Quality-control (QC) plasma samples of 5, 100, $5,000 \mathrm{ng} / \mathrm{ml}$ concentrations were prepared by using the same method described above.

\section{Instruments, chromatography and mass spectroscopy}

The determination of sorafenib was performed using the LC/MS/MS system, known as Quattro Premier ${ }^{\mathrm{TM}} \mathrm{XE}$ coupled with Alliance HPLC (2795XE separations module) made from Waters (Milford, NJ, USA). Separating column of HPLC system was a reverse-phase Waters XTerra ${ }^{\circledR}$ MS C18 column $(150 \mathrm{~mm} \times 2.1 \mathrm{~mm}$, i.d.) being packed with the stationary phase of $3.5 \mu \mathrm{m}$ diameter particles and operating at $35^{\circ} \mathrm{C}$ by a temperature-controlled heating device. The mobile phase was eluted in an isocratic manner, which consisted of eluent A $10 \%, \mathrm{~B} 30 \%$ and C $60 \%$, at the flow rate of $0.2 \mathrm{ml} / \mathrm{min}$. Eluent A was distilled water with $10 \mathrm{mM}$ ammonium formate containing $0.1 \%$ formic acid. Eluent $B$ consisted of $100 \%$ acetonitril and eluent C, 100\% methanol. Sample effluent passed through column was introduced into the interface of a triple quadrupole mass spectrometric detector equipped with an electrospray probe operating in electrospray positive-ionization mode $\left(\mathrm{ES}^{+}\right)$at a cone voltage of $40 \mathrm{KV}$ for sorafenib and $24 \mathrm{KV}$ for internal standard and the temperature of $350^{\circ} \mathrm{C}$. The programmed ion transitions of $[\mathrm{M}+\mathrm{H}]^{+}$were set at $\mathrm{m} / \mathrm{z} 465.2 \rightarrow 252.5$ for sorafenib and $\mathrm{m} / \mathrm{z} 484.4 \rightarrow 286.2$ for the internal standard to pass from the first quadrupole $(\mathrm{Q} 1)$ through the third quadrupole (Q3). The collision energy of the collision cell (Q2) was set at 36 $\mathrm{eV}$ for sorafenib and $22 \mathrm{eV}$ for the internal standard. This system was controlled by Waters MassLynx v4.1.

\section{Calibration curves and method validation}

According to the guideline of Korean Food and Drug Administration, the method was validated for selectivity, limit of quantification, extraction efficiency, linearity, accuracy, precision and stability [4]. All concentrations of calibration curves and QCs were calculated from the response obtained with the peak area ratio of sorafenib to chlorantraniliprole per sample using a weighted $\left(1 / x^{2}\right)$ least-squares linear regression analysis. The limit of detection (LOD) was selected as the concentration with more than 3 times signal to noise ratio $(\mathrm{S} / \mathrm{N})$ for peak height. It was selected as the lower limit of quantification (LLOQ), the lowest standard concentration among the quantifiable concentrations of the calibration curve when having at least more than 10 of S/N ratio, a precision of below $20 \%(\mathrm{CV}, \%)$ and an accuracy within the range of $80-120 \%$. The specificity of the method was tested by elucidating whether there were coincident peaks of endogenous or exogenous components in chromatograms of extracted human plasma originated from six different donors. The linearity was assessed by the correlation coefficient $\left(r^{2}\right)$ after the calibration curves were plotted to 5 copies within the following ranges; $2,5,50,100,500,1,000$, $5,000 \mathrm{ng} / \mathrm{ml}$. The accuracy and precision were validated by assessing 5 copies of QC sample concentrations $(2,5,100$, $5,000 \mathrm{ng} / \mathrm{ml}$ ) within one day (the intra-day assay) and also totally five copies from 5 consecutive days (the inter-day assay). The accuracy of the method was described by the percentage of calculated mean concentration to the nominal concentration of sorafenib for every QC concentration. The precision was described by the coefficient of variation $(\mathrm{CV}$, $\%$ ), the percentage of the standard deviation to mean concentration for all calculated QC concentrations at each levels. The extraction efficiencies of the assay were measured by comparing the peak areas of sorafenib passed through the extraction procedure from human plasma with aqueous standard solutions made by mobile phase in triplicates at the concentrations of the low, middle and high QCs. The short-term temperature stability and post-preparative stability of sorafenib in human plasma were tested. All stabilities were determined by using 3 copies of the low and high QCs $(5,5,000 \mathrm{ng} / \mathrm{ml})$. The short-term temperature stability was assessed by determining the levels after QC plasma samples had been kept at room temperature for 6 hours. The post-preparative stability was estimated by determining the concentrations after post-extraction samples had been kept in the auto-sampler for 24 hours. The short-term temperature stability and post-preparative stability were described by the percentage of determined mean concentrations to the nominal concentrations of sorafenib.

\section{Results}

\section{Ion transition}

The mass spectra of sorafenib and chlorantraniliprole showed the peaks of parent molecules at $m / 2465.2$ and 484.4 as a protonated molecular ion $\left([\mathrm{M}+\mathrm{H}]^{+}\right)$, respectively. The $[\mathrm{M}+\mathrm{H}]^{+}$of major fragments (daughter molecules) were observed at $m / 2252.5$ for sorafenib on the collision energy level of $36 \mathrm{eV}$ and at $\mathrm{m} / \mathrm{z} 286.2$ for chlorantraniliprole on $22 \mathrm{eV}$, which were detected for subsequent monitoring in the third 
quadrupole (Fig. 2).

\section{Specificity, linearity and extraction efficiency}

The retention time of sorafenib was about $2.6 \mathrm{~min}$. The limit of detection (LOD) was $100 \mathrm{pg} / \mathrm{ml}$ with the $\mathrm{S} / \mathrm{N}$ ratio of 4.7 (Fig. 3). The lower limit of quantification (LLOQ) was selected as $2 \mathrm{ng} / \mathrm{ml}$ which had the sufficient $\mathrm{S} / \mathrm{N}$ ratio of 42.3 and the $\mathrm{CV}$ of less than $10 \%$. No interfering peak of endogenous plasma component of blank plasma was detected at the retention time of sorafenib in the chromatograms of blank human plasma from six donors, as shown on the chromatogram of one human plasma among them (Fig. 4). The assay had the linearity over the concentration range $(2-5,000 \mathrm{ng} / \mathrm{ml})$. The linear-regression correlation coefficients $\left(r^{2}\right)$ were obtained with above the value of 0.99 in all standard curves. Its regression equation on the first day was 'y=0.0061 $\mathrm{x}+0.00155\left(r^{2}>0.999, p<0.01\right)$ ' As summar- ized in Table 1, the mean extraction efficiencies of sorafenib from plasma in the concentrations of $5 \mathrm{and} 5,000 \mathrm{ng} / \mathrm{ml}$ had the range of $40.2-47.4 \%$.

\section{Precision and accuracy}

The results were summarized in table 2 for the precision and accuracy data of the intra- and inter-day assay. The CV of the precision ranged from 3.7 to $9.4 \%$ in the intra-day assay and from 4.2 to $7.9 \%$ in the inter-day assay, which were all below $10 \%$. As the result of accuracy, there were the predicted concentrations in the range of $90.7-103.9 \%$ of the nominal QC concentrations, which were not deviated from the range between 90 and $110 \%$.

\section{Stability}

Sorafenib and chlorantraniliprole have shown a high stability in human plasma (table 3). When the QC samples were
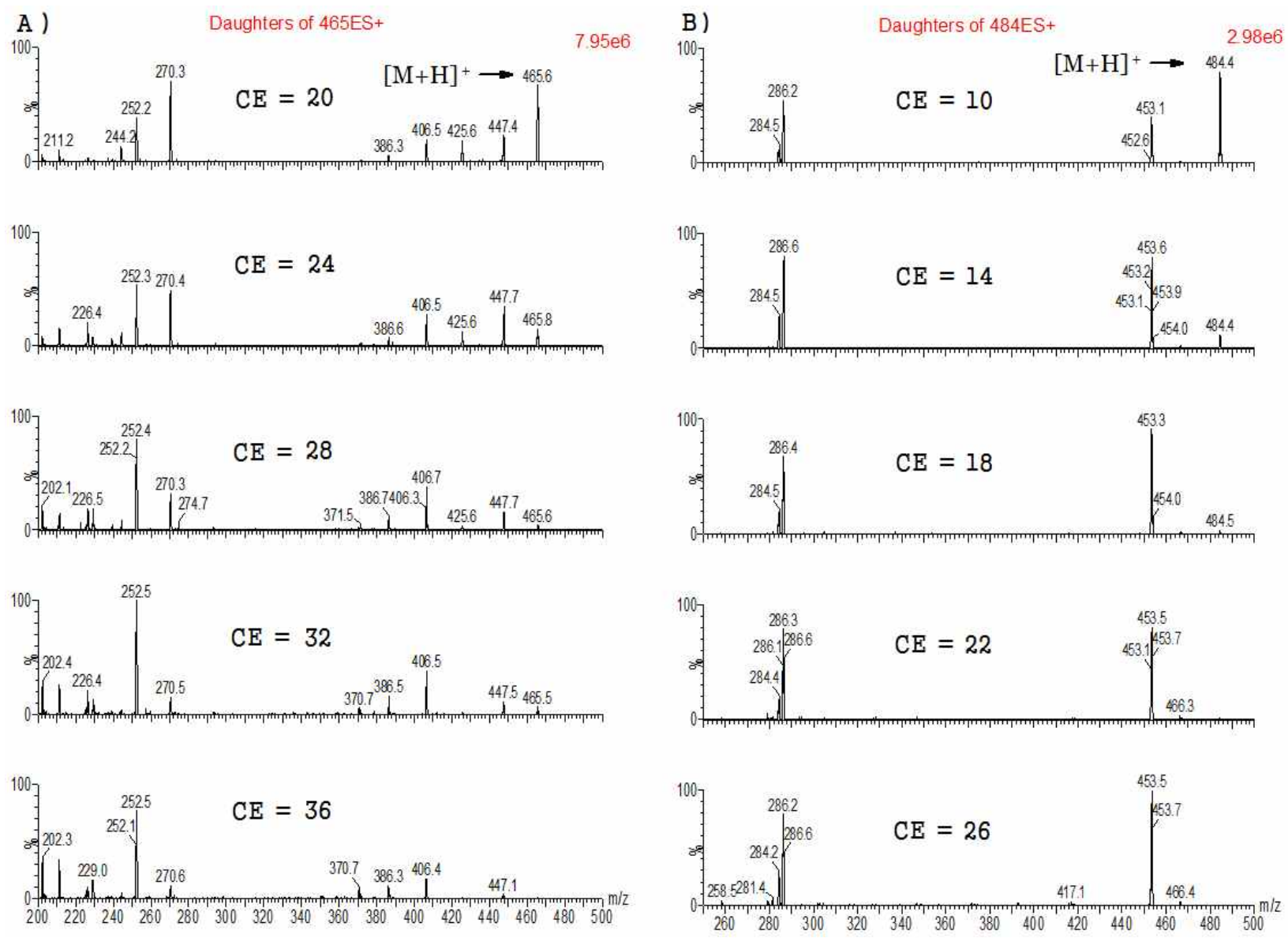

Fig. 2. Mass spectra of the product ions from sorafenib and chlorantraniliprole according to the collision energy. As the collision energy (CE) was increasing, the product ions were less smaller and parent ions $\left([\mathrm{M}+\mathrm{H}]^{+}\right)$were disappearing. A) Parent ions of sorafenib were at $\mathrm{m} / \mathrm{L} 465.2$ and major product ions of $\mathrm{m} / \mathrm{L} 252.5$ were increasing. B) Parent ions of chlorantraniliprole (internal standard) were at $\mathrm{m} / \mathrm{z} 484.4$ and product ions with of $\mathrm{m} / \mathrm{z} 286.2$ were appearing. 

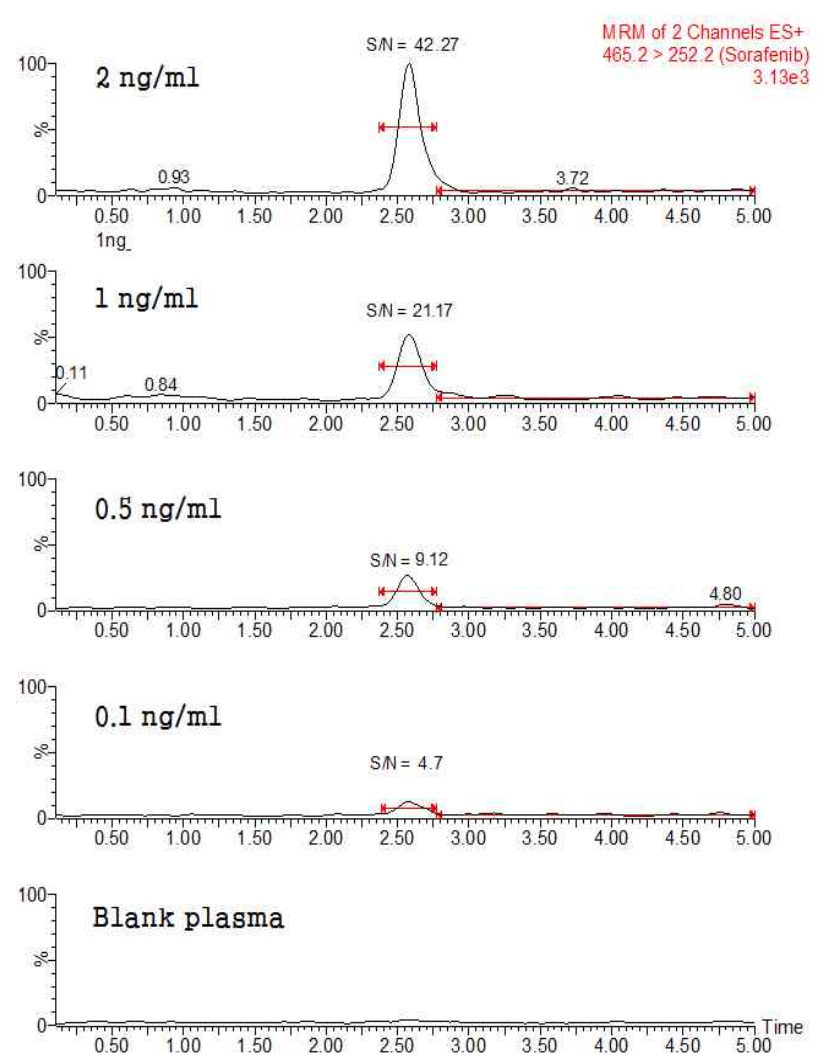

Fig. 3. Chromatograms of sorafenib in low concentrations. The limit of detection (LOD) of sorafenib is $0.1 \mathrm{ng} / \mathrm{ml}$ and the lower limit of quantification (LLOQ) is $2 \mathrm{ng} / \mathrm{ml}$ with the signal to noise $(\mathrm{S} / \mathrm{N})$ ratio of 42 .

extracted after they had been kept at a room temperature for 24 hours, their mean levels of predicted concentration were determined to be $105.4 \%$ for the low QC $(5 \mathrm{ng} / \mathrm{ml})$ and $107.6 \%$ for the high QC $(5,000 \mathrm{ng} / \mathrm{ml})$. In addition, the levels of sorafenib were estimated to have no significant degradation in the post-preparative and freeze-thaw stability tests $(90 \%<$ predicted concentrations ratio < $110 \%)$.

\section{Discussion}

In pharmacokinetic study, it was essential of the precise
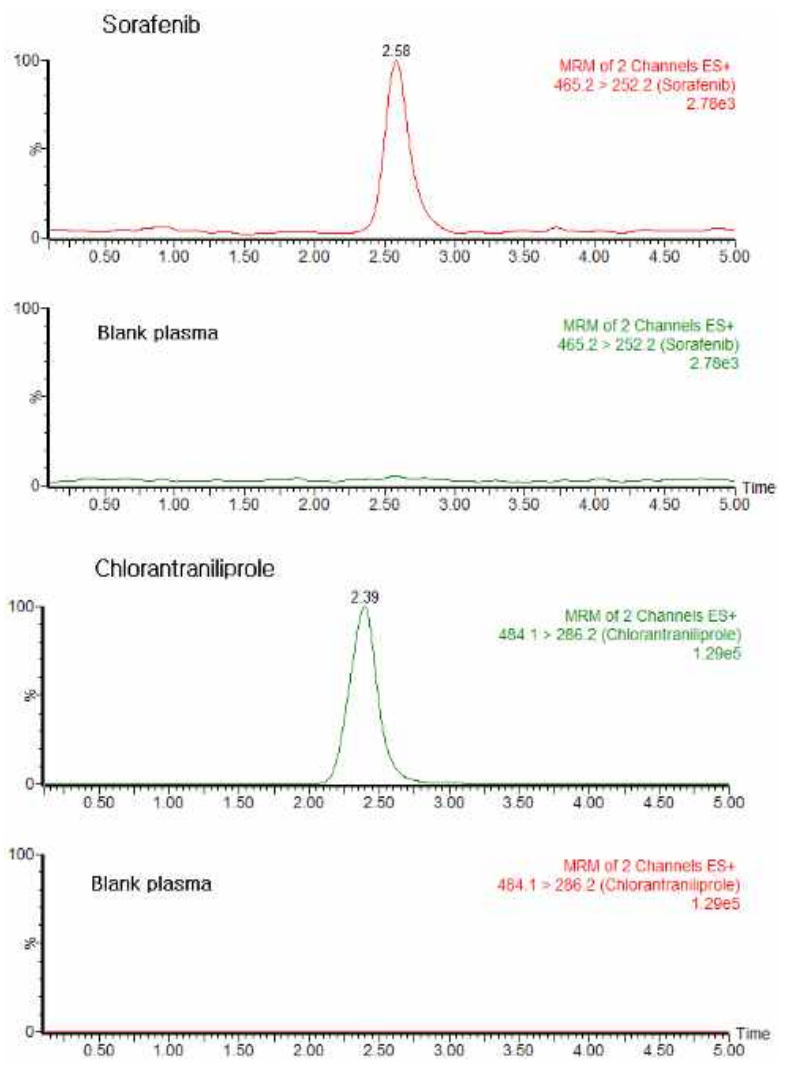

Fig. 4. Specific peaks of sorafenib and chlorantraniliprole in comparison to the peaks of blank plasma ingredients. There was no interfering peak of endogenous plasma component in blank plasma in comparison to the peaks of sorafenib (2 $\mathrm{ng} / \mathrm{ml})$ and chlorantraniliprole (20 $\mathrm{ng} / \mathrm{ml})$ spiked in plasma. The retention times for sorafenib and internal standard were approximately 2.6 $\min$ and $2.4 \mathrm{~min}$, respectively.

and accurate method for the determination of drug level in biological plasma. Conventional HPLC was previously used but recently replaced with LC/MS/MS system for sorafenib analysis in common with general chemical agents. Although ultra-performance lquid chromatography (UPLC) had superior separation efficiency than conventional HPLC because it had employed smaller particles of $1.7 \mu \mathrm{m}$ size in column, it had not been exploited in the analysis of sorafenib without

Table 1. Extraction efficiency of sorafenib from human plasma

\begin{tabular}{cccc}
\hline \multirow{2}{*}{$\mathrm{QC}^{\mathrm{a}}$} & \multicolumn{2}{c}{ Mean \pm SD $\left(\right.$ peak area $\left.{ }^{\mathrm{b}}\right)$} & \multirow{2}{*}{ Extraction efficiency $(\%)$} \\
\cline { 2 - 3 } & Preparation & No preparation & 42.3 \\
100 & $1156 \pm 127.4$ & $2731 \pm 514.4$ & 47.4 \\
5000 & $22998 \pm 2709.9$ & $48473 \pm 6761.7$ & 40.2 \\
\hline
\end{tabular}

${ }^{a}$ Quality control concentration $(\mathrm{ng} / \mathrm{ml}),{ }^{b}$ Peak areas of sorafenib in chromatograms were analyzed after extraction with sorafenib from human plasma or directly in organic solution without preparation Abbreviation: QC, Quality control samples; SD, Standard deviation 
Table 2. Accuracy and precision of method for the determination of sorafenib

\begin{tabular}{|c|c|c|c|}
\hline Nominal concentrations $(\mathrm{ng} / \mathrm{ml})$ & Predicted concentrations $($ Mean $\pm \mathrm{SD}, \mathrm{ng} / \mathrm{ml})$ & Accuracy $^{\mathrm{a}}(\%)$ & Precision $^{\mathrm{b}}(\mathrm{CV}, \%)$ \\
\hline \multicolumn{4}{|l|}{ Intra-day $(n=5)$} \\
\hline LLOQ & $1.9 \pm 0.14$ & 99.2 & 7.2 \\
\hline LQC & $5.2 \pm 0.49$ & 103.9 & 9.4 \\
\hline MQC & $90.7 \pm 3.35$ & 90.7 & 3.7 \\
\hline HQC 5000 & $5165.9 \pm 361.71$ & 103.3 & 7.0 \\
\hline \multicolumn{4}{|l|}{ Inter-day $(n=5)$} \\
\hline LLOQ & $2.0 \pm 0.16$ & 101.9 & 7.9 \\
\hline LQC & $5.0 \pm 0.28$ & 99.9 & 5.5 \\
\hline MQC & $95.8 \pm 5.62$ & 95.8 & 5.9 \\
\hline HQC 5000 & $5139.1 \pm 213.62$ & 103.8 & 4.2 \\
\hline
\end{tabular}

a (Predicted mean concentration/nominal concentration) $\times 100(\%),{ }^{b}(\mathrm{SD} /$ Mean) Estimated concentration $\times 100(\%)$

Abbreviation: LLOQ, Lower limit of quantification; LQC, Low concentration of quality control; MQC, Middle concentration of quality control; HQC, High concentration of quality control; SD, Standard deviation; CV, Coefficient of variation

Table 3. Stability assessment in human plasma

\begin{tabular}{ccc}
\hline Nominal concentrations $(\mathrm{ng} / \mathrm{ml})$ & Predicted concentrations $(\mathrm{n}=3$, Mean $\pm \mathrm{SD}, \mathrm{ng} / \mathrm{ml})$ & Stability $^{\mathrm{a}}(\%)$ \\
\hline Post-preparative stability $\left(10^{\circ} \mathrm{C}\right.$, for 6 hours) & $4.8 \pm 0.37$ & 96.3 \\
LQC 5 & $5297.0 \pm 443.74$ & 105.9 \\
HQC 5000 & & 105.4 \\
Short-term stability (room temperature, for 24 hours) & $5.3 \pm 0.26$ & 107.6 \\
LQC 5 & $5378.3 \pm 245.93$ & 96.1 \\
HQC 5000 & & 108.6 \\
Freeze-thaw stability $\left(-20^{\circ} \mathrm{C}\right)$ & $4.8 \pm 0.37$ & \\
LQC 5 & $5432.0 \pm 168.54$ & \\
HQC 5000 & & \\
\hline
\end{tabular}

a(Predicted mean concentration/nominal concentration) $\times 100(\%)$

Abbreviation: LQC, Low concentration of quality control; HQC, High concentration of quality control; SD, Standard deviation

mass spectrometry [6]. In this study, the method of sorafenib analysis in human plasma was developed by using LC/MS/MS. Human plasma should be processed before LC/MS/MS analysis in order to eliminate the interfering plasma ingredients and prevent the contamination of analysis system. Preparation methods for the determination of sorafenib in biological plasma can be categorized into three classes: protein precipitation, liquid-liquid extraction and solid-phase extraction. Zhao et al. used the protein precipitation which was simple and short-processing [10]. In early period of our method development, the protein precipitation was used and proved to be simple and speedy as mentioned by Zhao et al. However, several dozen injections seriously contaminated the column part and stopped the assay runs because of the high back pressure (data not shown). So HPLC system was required for frequent cleanup of the column part. Therefore, we developed the optimized liquid-liquid extraction method using the organic solution of isopropyl alcohol and ethyl acetate. Although long time process and low extraction efficiency (less than half), this preparation method achieved the stable back pressure of HPLC part even after several hundred injections. It was reported that conventional HPLC method had spend 35 minutes in one run [1] and LC/MS/MS method required 6 minutes [10]. However, newly developed LC/MS/MS method was able to finish one run within 5 minutes with high sensitivity. In this method, it was found that LLOQ $(2 \mathrm{ng} / \mathrm{ml})$ of this method was lower level as compared with other methods: 80 [1], 10 [7] and $7.3 \mathrm{ng} / \mathrm{ml}$ [10]. In conclusion, the lower limit of quantification of this method had forty-fold lower level as compared with $80 \mathrm{ng} / \mathrm{ml}$ in mouse plasma and a chromatographic run time per injection was reduced from 35 to 5 minutes. Sorafenib and internal standard were well separated without the background interferences of blank human plasma. Validation results showed the proper linearity $\left(r^{2}>0.99\right)$ over the range of $2-5,000 \mathrm{ng} / \mathrm{ml}$ with good accuracy $(90.7-103.9 \%)$ and precision (less than $10 \%$ ). A sensitive method has been developed and validated for the determi- 
nation of sorafenib in human plasma.

\section{References}

1. Afify, S., Rapp, U. R. and Hogger, P. 2004. Validation of a liquid chromatography assay for the quantification of the Raf kinase inhibitor BAY 43-9006 in small volumes of mouse serum. J. Chromatogr. B Analyt. Technol. Biomed Life Sci. 809, 99-103.

2. Escudier, B., Eisen, T., Stadler, W. M., Szczylik, C., Oudard, S., Siebels, M., Negrier, S., Chevreau, C., Solska, E., Desai, A. A., Rolland, F., Demkow, T., Hutson, T. E., Gore, M., Freeman, S., Schwartz, B., Shan, M., Simantov, R. and Bukowski, R. M. 2007. Sorafenib in advanced clear-cell renal-cell carcinoma. N. Engl. J. Med. 356, 125-134.

3. Hotte, S. J. and Hirte, H. W. 2002. BAY 43-9006: early clinical data in patients with advanced solid malignancies. Curr. Pharm Des. 8, 2249-2253.

4. KFDA Guidance for Industry, Bioanalytical method validation, National Institute of Toxicology Department. 2003. http://www.kfda.go.kr/

5. Llovet, J. M., Ricci, S., Mazzaferro, V., Hilgard, P., Gane, E., Blanc, J. F., de Oliveira, A. C., Santoro, A., Raoul, J. L., Forner, A., Schwartz, M., Porta, C., Zeuzem, S., Bolondi, L., Greten, T. F., Galle, P. R., Seitz, J. F., Borbath, I., Haussinger,
D., Giannaris, T., Shan, M., Moscovici, M., Voliotis, D. and Bruix, J. 2008. Sorafenib in advanced hepatocellular carcinoma. N. Engl. J. Med 359, 378-390.

6. Park, D. J. and Kim, W. M. 2009. The rapid determination of gemcitabine by reversed-phase ultra-performance liquid chromatography. J. Life Sci. 19, 1698-1704.

7. Sparidans, R. W., Vlaming, M. L., Lagas, J. S., Schinkel, A. H., Schellens, J. H. and Beijnen, J. H. 2009. Liquid chromatography-tandem mass spectrometric assay for sorafenib and sorafenib-glucuronide in mouse plasma and liver homogenate and identification of the glucuronide metabolite. J. Chromatogr. B Analyt. Technol. Biomed Life Sci. 877, 269-276.

8. Wilhelm, S. and Chien, D. S. 2002. BAY 43-9006: preclinical data. Curr. Pharm Des. 8, 2255-2257.

9. Wilhelm, S. M., Adnane, L., Newell, P., Villanueva, A., Llovet, J. M. and Lynch, M. 2008. Preclinical overview of sorafenib, a multikinase inhibitor that targets both Raf and VEGF and PDGF receptor tyrosine kinase signaling. Mol. Cancer Ther. 7, 3129-3140.

10. Zhao, M., Rudek, M. A., He, P., Hafner, F. T., Radtke, M., Wright, J. J., Smith, B. D., Messersmith, W. A., Hidalgo, M. and Baker, S. D. 2007. A rapid and sensitive method for determination of sorafenib in human plasma using a liquid chromatography/tandem mass spectrometry assay. $J$. Chromatogr. B Analyt. Technol. Biomed Life Sci. 846, 1-7.

\section{초록 : 고속액체크로마토그래피 텐덤질량분석기법을 이용한 사람 혈장 내 소라페닙 농도분석법의 개발 및 검정

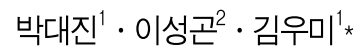 \\ ( ${ }^{1}$ 고신대학교 의과대학 약리학교실, ${ }^{2}$ 고신대학교 복음병원 가정의학과)}

소라페닙은 멀티카이네즈 억제제로서 신세포암, 전이성 간세포암 환자의 치료에 효과가 입증된 경구용 항암제 이다. 이 연구의 목적은 고속액체크로마토그래피 텐덤질량분석기법(LC/MS/MS)을 이용하여 사람 혈장 내 소라 페닙의 농도를 측정하는 효율적인 방법을 개발하고 한국식품의약품안전청(KFDA) 기준에 따라 분석법을 검정하 는 것이다. 혈장시료 $(100 \mu l)$ 에 내부표준물질인 chlorantraniliprole을 첨가한 후 이소프로필알콜과 에틸아세테이 트로 구성 $(1: 4, \mathrm{v} / \mathrm{v})$ 된 $0.1 \%$ 포름산 함유 추출용액을 혼합하였다. 원심분리 후 상층액을 취하여 원심감압농축하였 다. 잔사를 이동상에 재용해하고 Waters사의 역상 XTerra ${ }^{\mathrm{TM}} \mathrm{C} 18$ 칼럼(입자크기 $3.5 \mu \mathrm{m}$ )을 장착한 고속액체크로 마토그래피 장치에 주입하였다. 액체크로마토그래피는 $0.1 \%$ 포름산과 $10 \mathrm{mM}$ 암모늄 포메이트를 함유한 버퍼용 액과 메탄올, 아세토나이트릴을 각각 1:6:3으로 혼합한 용액을 이동상으로 사용하였으며 5분 내에 측정을 완료하 였다. 분석대상 물질들은 텐덤질량분석기에서 electrospray 양이온 이온화(ES+) 검출방식으로 확인하였으며 소라 페닙은 ' $m / 2465.2 \rightarrow 252.5$ ', chlorantraniliprole은 ' $m / 2484.4 \rightarrow 286.2$ '으로 구성한 multiple reaction monitoring 방법을 사용하였다. 검정 결과, $2-5,000 \mathrm{ng} / \mathrm{ml}$ 의 농도 구간에서 양호한 직선성 $\left(r^{2}>0.99\right)$ 과 정확도 $(90.7-103.9 \%)$, 정 밀도 $(10 \%$ 이하)를 나타내었다. 새롭게 개발된 LC/MS/MS을 이용한 사람 혈장 내 소라페닙의 농도 측정법은 $\mathrm{KFDA}$ 기준을 만족하였으며, 기존의 방법에 비해 민감도가 높은 방법이었다. 